\title{
Functional Genomics Study of Sick Neonate Affected with Chromosomal Rearrangements and Correlated with Clinical Phenotype: A 2 Year Survey of ICU in a Tertiary Care Hospital in Kolkata
}

\author{
Puspal D¹, Sudipa C1 ${ }^{1}$ Amit C ${ }^{1}$, Tushar KS ${ }^{2}$ and Santanu B ${ }^{2}$ \\ ${ }^{1}$ Institute of Genetic Engineering, 30 Thakurhat Road, Kolkata-128, India \\ ${ }^{2}$ Dr. BC Roy Post Graduate Institute of Pediatric Science, Phoolbagan Main Road, \\ Kolkata-59, India
}

*Corresponding author: Amit Chakravarty, Purbagana, 5 Ram Mohan Mallick Garden Lane, Beliaghata, Kolkata-10, India, Tel: 9903850960; Email: ige.amit@gmail.com

\section{Abstract}

In order to assess major chromosomal abnormalities among sick neonate with dysmorphic feature, mental retardation and delayed milestones in Kolkata, a chromosome aberration survey initiated in collaboration with Dr B.C. Roy Post Graduate Institute for Pediatric Science (Kolkata) is in progress. Since two years, we have screened about 120 sick neonates and children with indicated cases as per clinical findings. Cytogenetic analysis of blood lymphocytes were studied with High Resolution GTG-banding analysis by using Chromosome profiling (Cyto-vision software 3.6) on their chromosomes. The result shows significant amount of numerical and structural chromosomal abnormality. Among 120 selected sick neonates with dysmorphic fatures and pediatric cases, 22 cases have different chromosomal abnormalities. Among them 14 cases have numerical and 8 cases have structural chromosomal abnormality.

The present genetic screening result shows presence of syndromes caused by numerical chromosomal abnormality like Down Syndromes [1] Edwards syndrome, Patau syndrome, Turner syndrome [2] Sex Chromosomes [3] Others [1] and structural chromosome rearrangements [4]. Among structural chromosomal abnormality small deletion in 8p, 22q, 20p, $3 p$ and derivative 9, robertsonian translocation are found. Among the structural chromosomal rearrangement, two cases have shown typical clinical Phenotype (Beta-Thalassaemia associated with microcephaly, congenital Cataract and rare cases of micro deletion 1p 36), reported for the first time from India. We also found presence of mosaic cell line within same individual and severe hypodiploidy. We have correlated functional gene loci with clinical phenotypes of all 8 cases with chromosomal structural losses (bioinformatics approach) which will be a new approach for clinicians to evaluate and necessary management. This report provides valuable addition to the growing literature in Birth Defects Database.

Keywords: Chromosomal abnormality; Sick Neonate; Newborn and Children; Dysmorphic features; Genotype; Phenotype; Functional genomics 


\section{Genomics \& Gene Therapy International Journal}

\section{Introduction}

An estimated 2,76,000 babies die within 4 weeks of birth every year, worldwide, from congenital anomalies. It can result in long-term disability, which may have significant impacts on individuals, families, health-care systems and societies. The most common severe congenital anomalies are heart defects, neural tube defects and Down syndrome. Although congenital anomalies may be genetic, infectious, nutritional or environmental in origin, most often it is difficult to identify the exact causes. According WHO-2013, major structural anomalies appear in $2-3 \%$ in live newborns and other $2-3 \%$ is discovered in children up to 5 years old, summarizing 4-6\%. Birth defects are the first causes of infantile mortality, accounting for approximately $25 \%$ of all neonatal deaths. Minor anomalies appear in approximately $15 \%$ out of the total of newborns.

These anomalies do not alter the individual's health status, but they are associated with major defects in some cases, therefore they can serve as key elements for the diagnosis of more serious, hidden defects. In Indian scenario congenital malformation is the major cause of death of neonate and children in India. Genetic causes observed mainly are chromosomal anomalies, single or polygenic disorders. Chromosomal aberration in form of trisomy was mainly observed in malformed cases in India and $17 \%$ children exhibiting chromosomal anomalies with congenital malformation are known syndrome.

Malformations are a major cause of morbidity and mortality in full term infants and genomic imbalances are a significant component of their etiology. However, the causes of defects in many patients with multiple congenital malformations remain unexplained despite through clinical examination and laboratory investigations give rise to the frequency of Chromosomal aberration [3]. Chromosomal abnormalities are the major cause of congenital abnormalities in human genetic diseases, associated with, mental retardation, dysmorphic features, developmental delays, as well as multiple congenital anomalies [2,5]. The most common chromosome abnormalities in newborns are trisomy 21 and sex chromosome abnormalities [1].

In recent year sub-telomeric rearrangements have been identified as major cause of malformation syndrome. For detection of these kinds of chromosomal abnormalities, advanced cytogenetic techniques are needed particularly methods like FISH or CGH. The conventional method of detection of structural chromosomal instabilities involving CGH \& FISH has several difficulties like gene cloning for particular probe designing for newly rearranged loci. This, in turn, takes more time and money per patient, making it difficult to avail for a large scale population belonging to lower socioeconomic group.

To achieve optimal management and treatment for these patients the early diagnosis of these chromosomal disorders is very much important. So, standard chromosome analysis by karyotyping remains the first line test in routine diagnostic clinics. It is observed that in many pediatric wards in India, newborns with dysmorphic features and multiple congenital abnormalities sometimes are not genetically evaluated due to lack of Gene Testing facilities or Genetic counseling Clinic .It is a known fact that each chromosome have thousands of genes and it is not surprising that chromosomal disorders with clinically altered phenotype have large to minute structural chromosomal rearrangements which can be determined by the standard cytogenetic method.

It is also difficult to determine the cognitive impairment in neonatal period. In this scenario our main objective was to determine the unbalanced structural chromosomal abnormality such as partial chromosomal deletion or duplication or unbalanced rearrangements like partial trisomy or partial monosomy or unbalanced translocation. Though loss and gain analysis by chromosome profiling by Cytovision 3.92 software is an easy and cheap tool for diagnosis before genetic counseling, Standard chromosome analysis and chromosome profiling sometimes prove unrevealed, and still many cases remain as such where the patients left without diagnosis. Patients with atypical phenotypes for a particular syndrome or suspected for a syndromic case by the clinicians can proceed for diagnosis by florescence in situ hybridization or FISH and DNA based mutation analysis techniques ( Array CGH) for further confirmation.

In this study, we investigate 120 cases with multiple congenital abnormality, dysmorphic feature and mental retardation where 22 cases are identified as abnormal chromosomal constituent. Among these most of the cases are numerical chromosomal abnormalities like trisomies and presence of mosaic cell lines in autosomes as well as sex chromosome, about 8 cases, we found partial chromosomal deletion or duplication or unbalanced rearrangements like partial trisomy or partial monosomy 


\section{Genomics \& Gene Therapy International Journal}

or unbalanced translocation. We have performed FISH in a single case to determine the deletion in chromosome no 22 and hematological and DNA based mutation study in two suspected thalassaemic cases.

Present survey for chromosomal aberration among of sick neonates and children with dysmorphic features (Hospital record shows 75 unselected cases per month admitted in neonatal and pediatric intensive care unit or NICU \& PICU ) seems to be a significant data from India and this report provides additional information to the growing literature in Birth Defects Database.

\section{Materials and Methods}

\section{Sample Collection}

All the Specimens were collected from Neonatology Ward of Dr B.C. Roy Post Graduate Institute of Pediatric Sciences, Kolkata, along with patient data sheet contain all basic clinical information and investigation reports assigned by the attending consultant pediatricians as per our guide lines. The project proposal was approved by the Institute Ethical committee.

\section{Cytogenetic Analysis}

The Cells (Peripheral Blood) were cultured in culture media. The culture was then processed using standard protocol of leukocyte culture [6]. After processing of the culture, metaphases plate were prepared and subjected to G-T-G Banding technique [7] for analysis of the chromosome abnormalities, 20 metaphases plates were then analyzed.

\section{Chromosome Profiling}

Chromosome Profiling (CytoVision 3.92) was done to evaluate structural variation (Loss or Gain) in all GTB Chromosome analysis which is a new approach of chromosome analysis to detect submicroscopic structural rearrangements. Cyto-vision software, a very renowned software, for doing karyotyping, FISH and CGH analysis accurately and used popularly in many advanced cytogenetic laboratories in India and abroad. Using chromosome profiling, the in build feature of cyto-vision, detecting loss and gain of materials in rearranged chromosome is a new approach where the software aided techniques draws a graph of banding in grey level of the selected objects.

\section{FISH analysis}

The FISH protocol is divided into two stages. Denaturation and Hybridisation are performed on Day One. Washing and Detection are performed on Day Two. On day one, the DNA of the chromosomes and paints is denatured and the hybridization process (reannealing) takes place overnight. On day two, the slides are washed to remove unbound DNA sequences followed by detection, counterstaining and mounting [8]. Different probes and their binding region with color are clearly depicted in the Table 1.

\begin{tabular}{|c|c|}
\hline Name and Binding Site & Color \\
\hline Vysis Spectrum Aqua LSI 1q25 control probe, & Aqua \\
\hline Vysis Spectrum Orange LSI P58 (1p36) probe and & Orange \\
\hline Tel-vysion Spectrum Green probe for 22q13.3 region & Green \\
\hline Vysis LSI TUPLE1 (HIRA) Spectrum Orange probe for 22q11.2 region & Orange \\
\hline
\end{tabular}

Table 1: Name, color and binding region of the probes used in our study.

\section{Hematological Studies}

The two suspected thallasaemic patients were evaluated for Hemoglobin, Mean Cell Volume (MCV), Mean Cell Hemoglobin (MCH), Mean Cell Hemoglobin Concentration (MCHC), R.B.C.s, Red Cell Distribution Width (Rdw), Haematocrit (Hct) etc. by Automated Cell Counter (Medionic, Mark). The complete and final screening was done through $\mathrm{Hb}$-variant analysis by High Performance Liquid Chromatography (HPLC). Hb variants ( $\mathrm{HbA}, \mathrm{HbF}$ and $\mathrm{HbA} 2 / \mathrm{E}$ ) were estimated by HPLC (Variant I, Bio-Rad, USA) using manufacturer's protocol.

\section{Mutation Analysis}

DNA was isolated from white blood cells, using a DNA isolation kit for mammalian blood (Qiagen). Patients were screened for common $\beta$-Thalassaemia mutations of Eastern India like IVS 1-5(G-T), IVS1-5(G-C), codon 8/9 $(+\mathrm{G})$, codon $26(\mathrm{G}-\mathrm{A})$, and Fr. 41/42 (-TCTT) along with Cod 26 (G-A) for $\mathrm{HbE}$. The screening was performed by PCR based technique, Amplification Refractory Mutation System (ARMS) as described by Old JM. 


\section{Genomics \& Gene Therapy International Journal}

\section{Bioinformatics Analysis}

For bioinformatics study, after the detection of exact location of chromosomal rearrangement by wet laboratory technology, to predict genes presented within that particular position NCBI gene searching were done. Total number of genes on that position was determined. The total number of functional protein coding genes among all genes was identified. After that, clinical phenotypes for the alteration of each gene or mutated genes were studied thoroughly from NCBI and OMIM databases. Finally the phenotypes observed by the clinician during the present study were compared with the list of genes in the databases and find out the exact mutated genes in the databases, as because of these, each gene have a special phenotype when it was rearranged or mutated.

\section{Results}

The result shows that among 120 indicated cases (patient with dysmorphic features associated with congenital defects) 22 cases have chromosomal abnormality (14 cases have numerical defects and 8 cases with structural chromosomal instabilities). In numerical chromosomal abnormality 4 cases showed Down syndrome (Female $=2$ cases with karyotype $47 \mathrm{XX},+21$ and male $=2$ with karyotype $47 \mathrm{XY},+21$ ) , 2 cases are mosaic Down syndrome and single case of male with karyotype $46 \mathrm{XY} / 47 \mathrm{XY},+21$ ) or Down Syndrome variant with different degree of mosaicism, 2 are trisomy 18 or Edward syndrome (single case of male with karyotype $47 \mathrm{XX},+18$ and single case of female with karyotype $47 \mathrm{XY},+18$ ), 3 cases having trisomy 13 or Patau syndrome (single case of female with karyotype $47 \mathrm{XX},+13$ and two cases of male with karyotype $47 \mathrm{XY},+13$ ) were also detected. A single case of Tuner Syndrome (45;XO), 2 cases of mosaic Tuner Syndrome (46XX/45X0) or Turner Syndrome Variant with variable degree and single case of 46XX/46XY syndrome were also found in the present study (Table 2).

\begin{tabular}{|c|c|c|c|}
\hline Sl No & $\begin{array}{c}\text { Type of Chromosomal } \\
\text { Abnormality }\end{array}$ & Karyotype & Conclusion \\
\hline 1 & Numerical & $47 ; \mathrm{XX},(+21)$ & Down Syndrome \\
\hline 2 & Numerical & $47 \mathrm{XY},+21$ & Down Syndrome \\
\hline 3 & Numerical(Mosaic) & $46 \mathrm{XY} / 47 \mathrm{XY},(+21)$ & Down Syndrome Variant \\
\hline 4 & Numerical(Mosaic) & $46 \mathrm{XX} / 47 \mathrm{XX},+21$ & Down Syndrome Variant \\
\hline 5 & Numerical & $47 \mathrm{XX},+18$ & Edward Syndrome \\
\hline 6 & Numerical & $47 \mathrm{XY},+18$ & Edward Syndrome \\
\hline 7 & Numerical & $47 \mathrm{XY},+13$ & Patau syndrome \\
\hline 8 & Numerical & $47 \mathrm{XX},+13$ & Patau syndrome \\
\hline 9 & Numerical & $45 ; \mathrm{XO}$ & Turner Syndrome \\
\hline 10 & Numerical(Mosaic) & $46 \mathrm{XX} / 45 \mathrm{XO}$ & Turner Syndrome Variant \\
\hline 11 & Numerical & $46 \mathrm{XX} / 46 \mathrm{XY}$ & Sex chromosome abnormality \\
\hline 12 & Numerical & $41 \mathrm{XY} ;(-8,-9,-18,-21,-22), \mathrm{del} 10 \mathrm{q}$, del14q, del16p & Severe hypodiploidy \\
\hline 13 & Numerical & $39 ; \mathrm{XY}(-1,-11,-9,-20,-22$ & Severe hypodiploidy \\
\hline 14 & Numerical(Mosaic) & $\begin{array}{l}46 ; \mathrm{XY} / 46 ; \mathrm{XY},(-5,-10,-9,-12,-16)(+5 m a r k e r \\
\text { chromosomes). }\end{array}$ & $\begin{array}{c}\text { Severe hypodiploidy with } \\
\text { Marker Chromosomes }\end{array}$ \\
\hline
\end{tabular}

Table 2: Observed Numerical Chromosomal Abnormality.

Among the 8 cases of structural chromosomal abnormality, one case showed the karyotype 46XY,t(14q:21q)- a case of Down's Syndrome, one have the karyotype 46XY;del(22q)- a case of Di-gorge Syndrome, one have the karyotype 46XY; del(3p26.3), one have the karyotype with 46XY; del(20p) -it is a case of Allagile Syndrome and one have the karyotype with 46XY; der(9) and a single case of $8 p$ deletion syndrome with karyotype 46XY; del(8p). 


\section{Genomics \& Gene Therapy International Journal}

We also found 1 male and 1 female of 1 p36deletion syndrome with the karyotype of 46XY;del(1p36.21) and 46XX;(1p36.3) respectively (Table3). The photograph of the patients of these specific eight cases, the abnormal chromosomes, the chromosomal profiling results and finally the bio-informatically detected rearranged loci are depicted in Figure 1.

\begin{tabular}{|c|c|c|c|}
\hline SI No & Type of Chromosomal Abnormality & Karyotype & Conclusion \\
\hline 1 & Structural & $46 \mathrm{XY}, \mathrm{t}(14 \mathrm{q}: 21 \mathrm{q})$ & Down Syndrome Variant \\
\hline 2 & Structural & $46 \mathrm{XY}$;del(22q) & Di-gorge Syndrome \\
\hline 3 & Structural & $46 \mathrm{XY}$;el(3p26.3) & ALL \\
\hline 4 & Structural & $46 \mathrm{XY} ; \operatorname{del}(20 \mathrm{p})$ & Allagile Syndrome \\
\hline 5 & Structural & $46 \mathrm{XY} ; \operatorname{der}(9)$ & Derivative 9 syndrome \\
\hline 6 & Structural & $46 \mathrm{XY} ; \operatorname{del}(8 \mathrm{p})$ & $8 \mathrm{p}$ deletion Syndrome \\
\hline 7 & Structural & $46 \mathrm{XY}$;el(1p36.21) & 1p36 Deletion Syndrome \\
\hline 8 & Structural & $46 \mathrm{XX} ;(1 \mathrm{p} 36.3)$ & $1 \mathrm{p} 36$ Deletion Syndrome \\
\hline
\end{tabular}

Table 3: Observed Structural Chromosomal Abnormality.

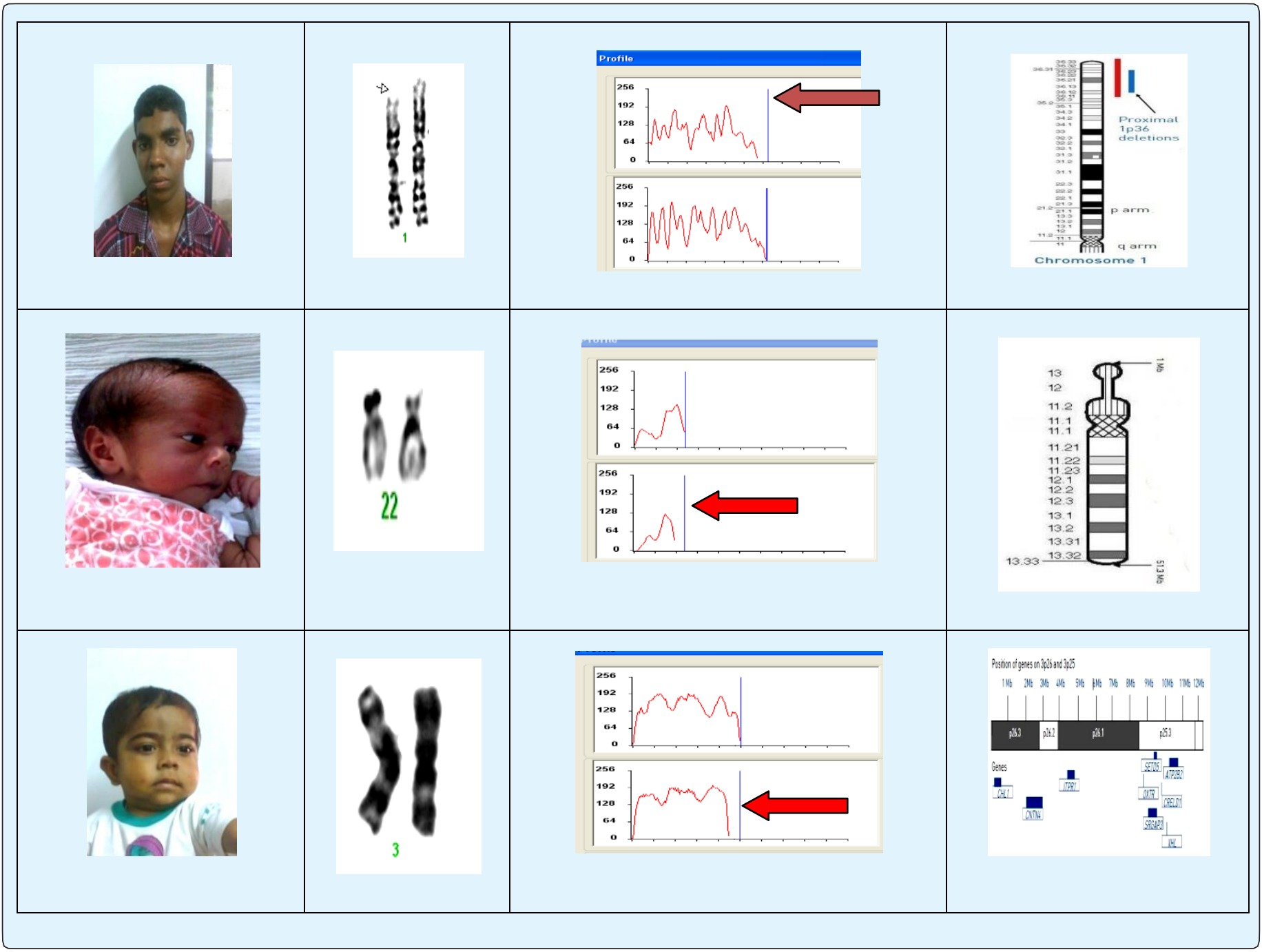

Amit C, et al. Functional Genomics Study of Sick Neonate Affected with Chromosomal Rearrangements and Correlated with Clinical Phenotype: A 2

Year Survey of ICU in a Tertiary Care Hospital in Kolkata. Genom \& Gene Ther Int J 2017, 1(1): 000101. 


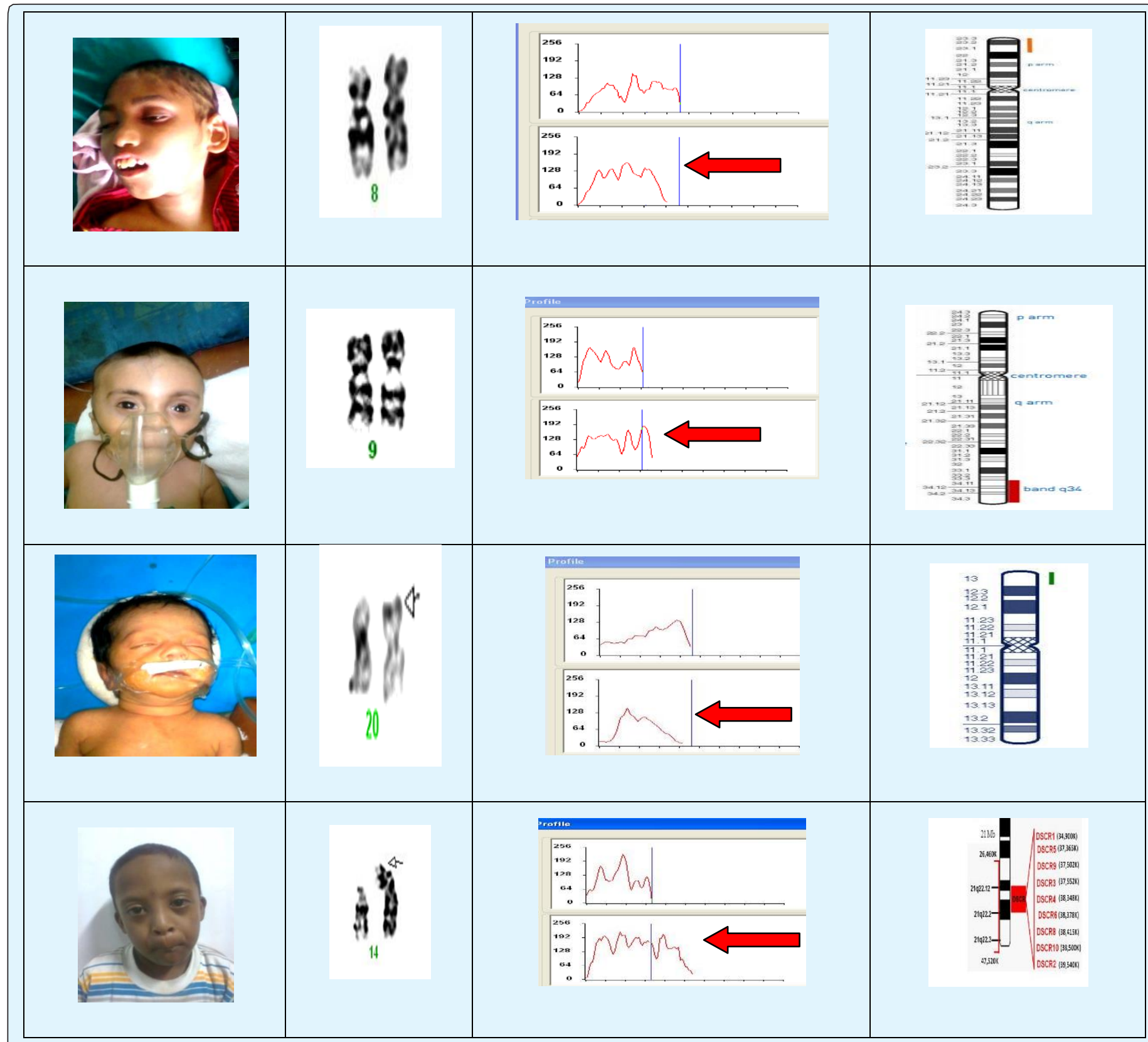

Figure 1: The figure shows the photograph of the patients, the abnormal chromosomes, the chromosomal profiling results and finally the bio-informatically detected rearranged loci in eight observed cases in the present study.

During the present study we also found two cases with severe hypodiploidy with the karyotype of $41 \mathrm{XY} ;(-8,-9,-$ $18,-21,-22)$,del10q, del14q, del16p and the second case $39 X Y ;(-1,-11,-9,-20,-22)$ and another case of mosaic hyperdiploidy with karyotype of 46;XY/46;XY,(-5,-10,-9,$12,-16)(+5$ marker chromosomes).

FISH analysis results shows single red signal of $22 \mathrm{q}$ locus specific probes instead of two due to deletion in specific locus and two green signals in centromere position in both the interphasic and metaphasic condition. The blue signals for counter stain DAPI. This result confirmed the small deletion in $22 q$ location. In another two cases with $1 \mathrm{p} 36$ deletion, Vysis Spectrum Aqua LSI 1q25 control probe shows two aqua color signals and Vysis Spectrum Orange LSI P58 (1p36) probe show single orange signal. The hematological study in the two suspected thalassaemic cases shows beta-talassaemia 


\section{Genomics \& Gene Therapy International Journal}

trait in one male patient and another female patients have HbE-beta thalassaemia. Mutation analysis study shows that IVS $1-5(\mathrm{G}-\mathrm{C}) /+$ in male and IVS $1-5(\mathrm{G}-\mathrm{C}) /$ Codon26 in female patient.

To evaluate functional genes loss in patient with submicroscopic chromosomal structural abnormality has been correlated with reference genome (Genome
Browser; Bioinformatics approach) and revealed respective gene losses of each patient genotype. As we found two cases of $1 \mathrm{p} 36$ deletion syndromes with different break position with Thalassaemia along with variable phenotypes, the comparative analysis of the two patients are clearly depicted in Table-4. And rests of the six cases, the detected genes with clinical functions for the respective loci are described in Table-5.

\begin{tabular}{|c|c|c|}
\hline Chromosome Analysis (GTB) result & $\begin{array}{c}\text { Normal Karyotype- means no } \\
\text { microscopic chromosomal } \\
\text { abnormality }\end{array}$ & $\begin{array}{c}\text { Normal Karyotype- means no } \\
\text { microscopic chromosomal } \\
\text { abnormality }\end{array}$ \\
\hline Chromosome Profiling result & $\begin{array}{c}\text { Detect loss of materials in } 1 \mathrm{p} 36.21 \\
\text { position }\end{array}$ & $\begin{array}{c}\text { Detect loss of materials in } 1 \mathrm{p} 36.3 \\
\text { position }\end{array}$ \\
\hline FISH Analysis & $\begin{array}{c}\text { Confirm loss of materials in } 1 \mathrm{p} 36 \\
\text { position }\end{array}$ & $\begin{array}{c}\text { Confirm loss of materials in } 1 \mathrm{p} 36 \\
\text { position }\end{array}$ \\
\hline Hematological Study & $\begin{array}{c}\text { Chromatogram shows Beta } \\
\text { thalasaemia trait }\end{array}$ & $\begin{array}{l}\text { Chromatogram shows HbE- } \beta \\
\text { thalassaemia }\end{array}$ \\
\hline Mutation analysis & $\begin{array}{l}\text { Found IVS } 1-5(\mathrm{G}-\mathrm{C}) /+, \text { confirming } \\
\text { the } \beta \text {-thalassaemia trait status }\end{array}$ & $\begin{array}{c}\beta \text {-globin mutation was found out to be } \\
\text { Cod } 26 \text { (G-A)/ IVS } 1-5 \text { (G-C), confirming } \\
\text { the HbE- } \beta \text { thalassaemia }\end{array}$ \\
\hline \multirow{4}{*}{$\begin{array}{l}\text { Genes involve for classical } 1 \text { p36 deletion } \\
\text { syndrome phenotype }\end{array}$} & 3genes & 3genes \\
\hline & - $M M P 23 B$ & - $M M P 23 B$ \\
\hline & - KCNAB2 & - KCNAB2 \\
\hline & - $S K I$ & 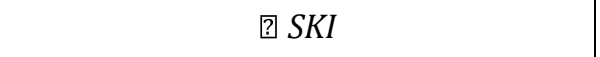 \\
\hline Total gene in $1 \mathrm{p} 36$ position & 922 & 922 \\
\hline $\begin{array}{l}\text { Functional protein coding genes in } 1 \mathrm{p} 36 \\
\text { position }\end{array}$ & 447 & 447 \\
\hline $\begin{array}{l}\text { Total genes present within specific deleted } \\
\text { portion }\end{array}$ & 101genes in $1 \mathrm{p} 36.21$ position & 8 genes in 1.36 .3 position \\
\hline $\begin{array}{l}\text { Functional protein coding genes in specific } \\
\text { deleted portion }\end{array}$ & 54 genes in 1 p36.21position & 1 gene in 1.36 .3 position \\
\hline \multirow{4}{*}{ Phenotype associated with deletion of } & 3genes & 1gene \\
\hline & - MMP23B & - MMP23B \\
\hline & - UBIAD1 & \\
\hline & - GLC3B & \\
\hline $\begin{array}{l}\text { Phenotypes like corneal dystrophy and } \\
\text { primary infantile }\end{array}$ & $\begin{array}{c}\text { Phenotype present in the individual } \\
\text { due to loss of two extra genes }\end{array}$ & Phenotype absent in the individual \\
\hline
\end{tabular}

Table 4: Summary of the case -1 and case -2 in the present study (Lab based and bioinformatics analysis). 


\section{Genomics \& Gene Therapy International Journal}

\begin{tabular}{|c|c|c|}
\hline $\begin{array}{l}\text { Submicroscopic } \\
\text { Chromosomal } \\
\text { rearrangements }\end{array}$ & $\begin{array}{l}\text { Name of } \\
\text { Gene }\end{array}$ & Function \\
\hline \multirow{8}{*}{ 22q micro-Deletion } & \multirow[b]{2}{*}{ SHANK3 } & - Mutations in this gene also cause schizophrenia type 15 \\
\hline & & $\begin{array}{l}\text { - Causative factor in the neurological symptoms of 22q13.3 deletion } \\
\text { syndrome }\end{array}$ \\
\hline & \multirow{3}{*}{ TCF20 } & $\begin{array}{l}\text { - Encodes a transcription factor that recognizes the platelet-derived } \\
\text { growth factor- }\end{array}$ \\
\hline & & - Responsive element in the matrix metalloproteinase 3 promoter. \\
\hline & & $\begin{array}{l}\text { - Mutations in this gene are associated with autism spectrum } \\
\text { disorders. }\end{array}$ \\
\hline & \multirow{3}{*}{ CELSR1 } & $\begin{array}{l}\text { - Encode protein of the flamingo subfamily, part of the cadherin } \\
\text { super family that does not interact with catenins. }\end{array}$ \\
\hline & & $\begin{array}{l}\text { - The flamingo cadherins are located at the plasma membrane and } \\
\text { have nine cadherin domains, seven epidermal growth factor-like } \\
\text { repeats and two laminin A G-type repeats in their ecto-domain. }\end{array}$ \\
\hline & & $\begin{array}{l}\text { - They also have seven trans-membrane domains, a characteristic } \\
\text { unique to this subfamily. }\end{array}$ \\
\hline \multirow{11}{*}{ 3p25 micro-deletion } & \multirow{2}{*}{ SETD5 } & $\begin{array}{l}\text { - Code a protein that found throughtout the body, espsecially in } \\
\text { brains. }\end{array}$ \\
\hline & & - Production of small amount protein creates the clinical feature. \\
\hline & \multirow[b]{2}{*}{ ITPR1 } & - Associated with a type of movement disorder. \\
\hline & & $\begin{array}{l}\text { - Conditions have a slowly progressive difficulty in walking and } \\
\text { coordination. }\end{array}$ \\
\hline & CRELD1 & Deletion or mutation causes heart defect. \\
\hline & SRGAP3 & Deletion or mutation cause Developmental delay \\
\hline & CHL1 & Deletion or mutation cause Learning difficulty \\
\hline & CNTN4 & Play role in the developing nervous system and neural network \\
\hline & $A T P 2 B 2$ & Deletion or mutation causes permanent hearing impairment \\
\hline & $V H L$ & $\begin{array}{c}\text { Deletion or mutation causes abnormal growth of blood vessel and } \\
\text { tumor }\end{array}$ \\
\hline & OXTR & Unknown \\
\hline & \multirow{4}{*}{ MCPH1 } & - Encodes a DNA damage response protein. \\
\hline & & $\begin{array}{l}\text { - May play a role in G2/M checkpoint arrest via maintenance of } \\
\text { inhibitory phosphorylation of cyclin-dependent kinase } 1 .\end{array}$ \\
\hline & & $\begin{array}{l}\text { - Mutations in this gene have been associated with primary } \\
\text { autosomal recessive microcephaly } 1\end{array}$ \\
\hline & & - Premature chromosome condensation syndrome \\
\hline & TNKS & Mutation and deletion causes behavioral problem/autism \\
\hline
\end{tabular}




\section{Genomics \& Gene Therapy International Journal}

\begin{tabular}{|c|c|c|}
\hline \multirow{10}{*}{ 8p micro-deletion } & \multirow{5}{*}{ GATA4 } & $\begin{array}{l}\text { - Encodes a member of the GATA family of zinc-finger transcription } \\
\text { factors. }\end{array}$ \\
\hline & & $\begin{array}{l}\text { - Recognize the GATA motif which is present in the promoters of } \\
\text { many genes. }\end{array}$ \\
\hline & & $\bullet$ Regulate genes involved in embryogenesis. \\
\hline & & - Myocardial differentiation and function. \\
\hline & & - Normal testicular development. \\
\hline & \multirow{5}{*}{ SOX7 } & $\begin{array}{l}\text { - Encodes a member of the SOX (SRY-related HMG-box) family of } \\
\text { transcription factors. }\end{array}$ \\
\hline & & •Involved in the regulation of embryonic development. \\
\hline & & $\bullet$ Determination of the cell fate. \\
\hline & & $\begin{array}{l}\text { - May act as a transcriptional regulator after forming a protein } \\
\text { complex with other proteins. }\end{array}$ \\
\hline & & - The protein may play a role in tumorogenesis. \\
\hline \multirow{5}{*}{ 9q micro-duplication } & \multirow{3}{*}{ EHMT1 } & $\begin{array}{l}\text { - Encoded a histone methyltransferase that is part of the E2F6 } \\
\text { complex, which represses transcription. }\end{array}$ \\
\hline & & $\begin{array}{l}\text { - Encoded protein methylates the Lys-9 position of histone H3, } \\
\text { which tags it for transcriptional repression. }\end{array}$ \\
\hline & & $\begin{array}{l}\text { - Involved in the silencing of MYC- and E2F-responsive genes and } \\
\text { therefore could play a role in the G0/G1 cell cycle transition. }\end{array}$ \\
\hline & \multirow{2}{*}{ CRAT } & $\begin{array}{l}\text { - Encodes carnitine acetyltransferase (CRAT), which is a key enzyme } \\
\text { in the metabolic pathway in mitochondria, peroxisomes and } \\
\text { endoplasmic reticulum. }\end{array}$ \\
\hline & & $\begin{array}{l}\text { - CRAT catalyzes the reversible transfer of acyl groups from an acyl- } \\
\text { CoA thioester to carnitine and regulates the ratio of acylCoA/CoA in } \\
\text { the sub-cellular compartments }\end{array}$ \\
\hline \multirow{5}{*}{$20 \mathrm{p}$ micro-deletion } & \multirow{4}{*}{ SOX12 } & - Members of the SOX family of transcription factors \\
\hline & & $\begin{array}{l}\text { - Characterized by the presence of a DNA-binding high mobility } \\
\text { group (HMG) domain, }\end{array}$ \\
\hline & & $\begin{array}{l}\text { - Homologous to the HMG box of sex-determining region Y (SRY). } \\
\text { Forming a subgroup of the HMG domain super family }\end{array}$ \\
\hline & & $\begin{array}{l}\text { - SOX proteins have been implicated in cell fate decisions in a diverse } \\
\text { range of developmental processes. }\end{array}$ \\
\hline & \multirow[t]{3}{*}{ NRSN2 } & $\begin{array}{l}\text { - NRSN2, is a homolog of Neurop24/Neurensin-1, } \\
\text { • Encodes a small neuronal membrane protein. }\end{array}$ \\
\hline & & $\begin{array}{l}\text { - Expression is limited in brain tissues including cerebral cortex, } \\
\text { thalamus/hypothalamus and hippocampus. }\end{array}$ \\
\hline & & $\begin{array}{l}\text { - Intra-cellularly, neurensin-2 is localized in small vesicles in neural } \\
\text { cells }\end{array}$ \\
\hline
\end{tabular}




\begin{tabular}{|c|c|c|}
\hline \multirow{4}{*}{14,21 Translocation DS } & \multirow{4}{*}{ DSCR1 } & $\begin{array}{c}\bullet \text { Encoded protein interacts with calcineurin A and inhibits } \\
\text { calcineurin-dependent signaling pathways, possibly affecting central } \\
\text { nervous system development. }\end{array}$ \\
\hline & & $\begin{array}{c}\text { - This gene is located in the minimal candidate region for the Down } \\
\text { syndrome phenotype, and is over expressed in the brain of Down } \\
\text { syndrome fetuses. }\end{array}$ \\
\hline & & $\begin{array}{l}\text { - Chronic over expression of this gene may lead to neurofibrillary } \\
\text { tangles such as those associated with Alzheimer disease. }\end{array}$ \\
\hline & & - Alternative splicing results in multiple transcript variants \\
\hline
\end{tabular}

Table 5: Functional gene losses due to chromosomal rearrangement in respective chromosome; Bio-informatics approach: OMIM \& NCBI Database).

\section{Discussion}

A number of children on doubt are usually evaluated by teams of professionals, including a pediatric neurologist or developmental pediatrician, a psychologist, speech pathologist, occupational or physical therapist, special educator, social worker, or even nurse. Doctors evaluate a suspected congenital malformed child by clinical examination and intellectual functioning and diagnose a cause. Even though the cause of the child's malformation may be irreversible, identifying a disorder that caused the disability may allow doctors to predict the child's future course, prevent further loss of skills, plan any interventions that can increase the child's level of functioning, and counsel parents on the risk of having another child with that same disorder. In present studies all the suspected sick neonate were referred for routine cytogenetic diagnostic laboratory to confirm differential diagnosis as per clinical findings.

Congenital anomalies are also known as birth defects, congenital disorders or congenital malformations. Congenital anomalies can be defined as structural or functional anomalies that occur during intrauterine life and can be identified prenatally, at birth or later in life. As genetic and malformative disorders are very diverse, appear at different ages and affect any system or organ, the patients who suffer of these diseases should be examined by a specialist doctor, who after applying the general methodology of genetic examination, should be able to indicate the necessary genetic explanations, as well as to correctly understand and interpret their results and should be able to advice genetically in a correct manner - within his/her area of competence - the extent of genetic risk of the patient and/or the family facing- if any.
Routine cytogenetic diagnosis involving microscopic chromosomal variation is normally based on an International System for Human Cytogenetic Nomenclature (ISCN-2005), and is not actually easy to identify. Chromosomal abnormalities like aneuploidies, marker chromosome, gross rearrangements and also variation in chromosome size are usually detected with optical microscopes. The frequency of these abnormalities in human population is thought to be as 1 in every 375 live births by putative information [10]. Some genetic diseases are the suspected outcome of these structural variations, but the relationships are not very certain. It is not plausible to divide these variants into two classes as "normal" or "disease" straightway, because the actual output of the same variant often also vary. Structural variations also have o role in population genetics. Different frequency of a same variation can be used as a genetic mark to infer relationship between populations in different areas.

To detect submicroscopic chromosomal rearrangements cytogeneticists advice advance molecular cytogenetic methods like FISH (Fluorescence In Situ Hybridization) or CGH (Comparative Genomic Hybridization). All these methods are used to detect submicroscopic chromosomal rearrangements but the accuracy depends on the design of probe. So, using the commercially available probe can help to detect submicroscopic chromosomal rearrangements only by the known disease locus. The unknown locus involved in chromosomal rearrangement or new mutation or rearrangement occurs de novo during gametogenesis can only be detected by more lengthy process which need probe designing using the new locus with BAC or YAC.

In this scenario the methods adopted to detect submicroscopic rearrangement in the present study is a 


\section{Genomics \& Gene Therapy International Journal}

new approach of the known methods. It reduced the cost and time of the test which makes it more suitable for diagnostic purpose as well as population study. In this process, the first line of screening is done by cytogenetic evaluation and the genetic alteration in microscopic level or in submicroscopic level is determined. At this point, patients with normal karyotype with clinical manifestation should be under consideration as no correlation between genotype and phenotype is often found. Genotype showing normal characteristic can show a phenotype showing the diseased condition.

In the next step chromosome profiling is done with the help of cyto-vision 3.92 software in all suspected or clinically identified syndromic patients whose karyotype is apparently normal. The software mainly scan all the homologous chromosomes and compare them digitally in point to point position which may help to identify the loss or gain of genetic materials at any point between these two homologous chromosomes. So, deletion or duplication or any haplo-insufficiency which cannot be determined by conventional karyotyping method could easily be identified by chromosome profiling.

As the deletion or duplication is invisible in routine karyotype but detected by digital software aided technology, it could be easily comparable as microdeletion or micro-duplication. In our present study for confirmation of the loss or gain of material in particular position, 20 good qualities of metaphase spreads are taken for observation and in each metaphase spread all 23 pairs of homologous chromosomes are analyzed by chromosome profiling with help of Cyto-vision 3.92 software. Manual processing and staining produces length variability in same homologous chromosome in different metaphase spread which some time creates problems to the identification of rearranged locus. To resolve this problem, a large number good quality metaphase spreads within the suspected individual are taken for analysis.

Next a question can arise that is the software aided chromosome profiling can actually determine the loss or gain in submicroscopic level. Is any wet lab with advanced molecular technology can confirm the same? To answer this point, three FISH analysis were performed in three different suspected patients during the present study. In the first case, conventional karyotyping method revealed normal chromosomal constituent and the hematological and mutation analysis study confirm the beta Thalassaemia trait status. But, still the phenotype does not match with the genotype in this case which was further confirmed by the software aided chromosome profiling and revealed the loss of materials in $1 \mathrm{p} .36 .21$ band position.

For cross checking commercially available aqua colored, Vysis Spectrum Aqua LSI 1q25 control probe and orange colored, Vysis Spectrum Orange LSI P58 (1p36) probe mix are used for FISH analysis. The FISH analysis result strongly agrees with the result found in chromosome profiling. In the second case, only chromosome profiling indicates the loss in the genetic materials in chromosome $1 \mathrm{p} 36.3$ in spite of normal karyotype in conventional GTB method. In third case, for further cross checking, commercially available, Tel-vysion Spectrum Green probe for 22q13.3 region and Vysis LSI TUPLE1 (HIRA) Spectrum Orange probe for 22q11.2 region are used for FISH analysis which again strongly supports the findings of chromosome profiling.

In order to understand the genes involved in rearranged chromosomal region another dry lab approach was taken for consideration. The gene search or genome analysis by bioinformatics approach with the help of several bioinformatics sites like NCBI and OMIM search stands as a good tools for this purpose. As for example, according to the present study, the two sites in 1 p36 position containing 927 genes and among them 446 were functional protein coding genes.

But literature based study revealed that only three genes in this specific region are mainly responsible for the clinical features of classical 1p36 deletion syndrome. The clinical manifestation and the severity were reported to be altered according to the involvements of more mutated genes. In the second case of the present study, where the chromosomal rearrangement mainly restricted in $1 \mathrm{p} 36.3$ position, NCBI and OMIM search shows presence of 8 genes in this region and among these 7 genes were functional protein coding genes. But only single gene is reportedly identified in this region responsible for classical 1p36 deletion syndrome.

This genotypical information exactly matches with the phenotypes of the aforesaid patient and due to the absence of that particular gene responsible for classical $1 \mathrm{p} 36$ deletion syndrome, the other characteristic features like structural abnormalities of the brain, seizures, weak muscle tone (hypotonia) and swallowing difficulties (dysphagia) were completely absent in the suspected patient. In the first case, the rearrangement restricted mainly in $1 \mathrm{p} 36.21$ position. Larger the rearranged portions more numbers of genes get involved. In this particular case 101 genes are involved and among which 


\section{Genomics \& Gene Therapy International Journal}

only 54 genes were functional protein coding gene of which three genes for phenotypic effect of classical 1p36 deletion syndrome were identified. So, the severity of the patient and the clinical manifestation has been enhanced.

Bioinformatics study also revealed that two genes namely UBIAD1 and GLC3B are situated in this chromosomal region with their respective band positions 1p36.22 and 1p36.21. Mutation or deletion in the UBIAD1 gene causes corneal dystrophy and opacification where mutation or deletion in the GLC3B gene causes primary infantile and glaucoma. So, in our reported first case these two genes must be deleted or mutated producing opacification or congenital eye cataract in the patients. The significance of the new approach of the genome analysis is that, it could detect the numbers of involved genes in rearranged portion of the chromosome and their clinical manifestation along with phenotypic correlation where both advance cytogenetic method and chromosome profiling can detect the exact location of submicroscopic chromosomal instabilities. The bioinformatics study of other six cases also revealed several involved genes in particular rearranged portions which significantly correlate with the phenotypes.

This present study depicted new approaches to understand chromosomal structural variation in West Bengal, in which we had screened chromosomal abnormalities among the neonates and children with dysmorphic features associated with congenital defects admitted in the hospital. All the patients were clinically examined by attending clinician, registered and selected for present studies. Most of the patients were admitted with severe critical condition and follow up for repeat specimens were failed due to sad demise or referring to other Hospitals for further managements.

In 8 out of 22 patients in this study, the aberration occurred de novo; two of them had complex rearrangements with both duplication and a deletion. As shown by testing the parental samples, only one abnormality detected in this study was derived from a parental balanced translocation. We have correlated with each patient Genotype (chromosomal structural loss or gain) and functional gene losses in the same respective region of Chromosome (based on Genome BrowserBioinformatics approach- see table- 3)) and same correlation revealed functional gene losses of each patients (Functional Genomics) which could be very useful for further management (? Gene Therapy) of each patient individually.
Funding statement: "This research received no specific grant from any funding agency in the public, commercial or not-for-profit sectors. All the research work done by the affiliated institutions' funding.

Competing Interests Statement: The authors declare that they have no competing interests.

Data Sharing Statement: We cannot share any unpublished data with other laboratory or person.

Patients Consent Statement: the signed consent from all the patients are taken before test was performed and kept them as official documents. In case of any unusual condition it will be presented in front of the concern persons.

\section{References}

1. O'Connor C (2008) Chromosomal Abnormalities. Aneuploids, Nature Edition 1(1): 172.

2. Boyd PA, Loane M, Garne E, Khoshnood B, Dolk H (2011) Sex chromosome trisomies in Europe: prevalence, prenatal detection and outcome of pregnancy. Eur J Hum Genet 19(2): 231-234.

3. Wellesley D, Dolk H, Boyd PA, Greenlees R, Haeusler $\mathrm{M}$, et al. (2012) Rare chromosome abnormalities, prevalence and prenatal diagnosis rates from population-based congenital anomaly registers in Europe. Eur J Hum Genet 20(5): 521-526.

4. Le Caiqnec $C$, Boceno $M$, Saugier VP, Jacquemont S, Joubert M, et al. (2005) Detection of Genomic Imbalances by Array based comparative genomic hybridization in fetuses with multiple malformations J Med Genet 42(2): 121-128.

5. Verna RS, Babu A (1989) Human Chromosomes: Manual of Basic Techniques, Pergamon Press, New York 71-72.

6. Seabright $M$ (1971) A rapid banding technique for human chromosomes. Lancet 2: 971-972.

7. Driscoll DA, Salvin J, Sellinger B, Budarf ML, Zackai $\mathrm{EH}$, et al. (1993) Prevalence of 22q11 microdeletions in DiGorge and velo-cardio-facial syndromes: implications for genetic counseling and prenatal diagnosis. J Med Genet 30: 813-817.

8. Old JM (1991) Methods in Molecular Biology; Protocols in Human Molecular Genetics; Detection of Mutations by the Amplification Refractory Mutation System (ARMS) Vol 9, p 77-84. 


\section{Genomics \& Gene Therapy International Journal}

9. Wyandt HE, Tonk VS (2004) Atlas of Human Chromosome Heteromorphisms. Netherlands: Kluwer Academic, ISBN 978-90-481-6296-3.

11. Ravnan JB, Tepperberg JH, Papenhausen $\mathrm{P}, \mathrm{Lamb}$ AN, Hedrick J, et al. (2006) Subtelomere FISH analysis of 11688 cases: an evaluation of the frequency and pattern of subtelomere rearrangements in individuals with developmental disabilities. J Med Genet 43(6): 478-489.

12. Knight SJ, Regan R, Nicod A, Horsley SW, Kearney L, et al (1999), Subtle chromosomal rearrangements in children with unexplained mental retardation. Lancet 354: 1676-1681.
13. Shaffer LG, Coppinger J, Alliman S, Torchia BA, Theisen A, et al (2008)Comparison of microarraybased detection rates for cytogenetic abnormalities in prenatal and neonatal specimens Prenatal Diagnosis 28(9): 789-795

14. Baker E, Hinton $L$, Callen DF, Altree $M$, Dobbie A, et al (2002) Study of 250 children with idiopathic mental retardation reveals nine cryptic and diverse subtelomeric chromosome anomalies, American Journal of Medical Genetics 107(4): 285-293.

15. World health organization (2006) Management of birth defects and haemoglobin disorders: Report of a Joint WHO-March of Dimes meeting. Geneva, Switzerland, WHO. 